\title{
SATU MESIN DWI FUNGSI SEBAGAI MESIN PEMBERSIH SERABUT DAN PEMARUT KELAPA DI BANJAR MUDING KELOD DESA KEROBOKAN KAJA KECAMATAN KUTA UTARA KABUPATEN BADUNG
}

\author{
K.Astawa $^{1}$, I.P.Lokantara ${ }^{2}$, H. Wijaksana ${ }^{3}$, dan T. P Surya ${ }^{4}$
}

\begin{abstract}
ABSTRAK
Kelapa dalam bahasa Latin disebut Cocos nucifera merupakan tanaman yang termasuk dalam jenis tanaman palma dengan buah yang berukuran cukup besar dibanding dengan tanaman jenis palma yang lain. Di Bali buah kelapa sering digunakan dalam pelaksanaan upacara keagamaan khususnya umat Hindu, seperti untuk kelengkapan banten Daksina. Dalam pembuatan kelapa daksina ini terlebih dahulu kelapa perlu dibersihkan dari serabutnya, tetapi untuk membersihkan serabut dibatok kelapa tersebut saat ini dilaksanakan secara konvensional sehingga membutuhkan waktu yang lama dan hasilnya tidak maksimal serta kurang efisien. Dilain pihak kebutuhan akan kelapa daksina di Bali sangat banyak sebagai unsur dalam pembuatan banten daksina. Selain sebagai kelengkapan daksina, kelapa juga bisa dipergunakan untuk bahan minyak goreng atau lawar. Untuk pembuatan minyak goreng, kelapa terlebih dahulu harus diparut. Biasanya untuk bisa memarut kelapa, batoknya harus dipecahkan sampai retak kecil-kecil untuk memudahkan dicongkel daging kelapanya, dengan cara ini sisa batoknya hanya bisa digunakan sebagai bahan bakar (arang) saja. Dengan menggunakan satu mesin dua fungsi ini yaitu sebagai pembersih batok dan pemarut kelapa menjadikan kedua pekerjaan ini akan dilakukan lebih efektif dan efisien karena untuk memarutnya, kelapa hanya cukup dibelah dua saja tanpa harus mencongkel daging kelapanya, dengan demikian batok kelapanya dapat dipergunakan sebagai kerajinan tangan atau souvenir untuk menunjang pariwisata sehingga dapat meningkatkan penghasilan atau pendapatan masyarakat setempat. Hasil pengujian langsung dilapangan menunjukan efisiensi dan efektifitas waktu antara cara konvensional dibandingkan dengan mesin adalah $15: 2$ menit untuk pembersihan serabut kelapa dan waktu untuk pemarutan setiap butir kelapa diperoleh perbandingan waktu $30: 10$ menit dengan batok kelapa hanya dibelah dua saja.
\end{abstract}

Kata kunci : Mesin, Pembersih, Pemarut, Kelapa

\section{PENDAhULUAN}

Kelapa dalam bahasa Latin disebut Cocos nucifera merupakan tanaman yang termasuk dalam jenis tanaman palma dengan buah yang berukuran cukup besar dibanding dengan tanaman jenis palma yang lain. Tumbuhan yang satu ini dimanfaatkan hampir di semua bagiannya untuk menunjang kehidupan terutama bagi manusia oleh karena itu tanaman kelapa dianggap sebagai tumbuhan yang multi guna.Di Bali buah kelapa sering digunakan dalam pelaksanaan upacara keagamaan khususnya umat Hindu. Karena begitu banyaknya kebutuhan akan buah kelapa bagi masyarakat Bali untuk persembahyangan atau upacara adat, terkadang mengakibatkan Bali kekurangan pasokan akan buah kelapa, sehingga untuk pemenuhannya harus mendatangkan dari luar Bali. Hasil perkebunan buah kelapa untuk saat ini masih banyak untuk dicari daging buah kelapanya saja yang diolah menjadi minyak goreng atau

\footnotetext{
${ }^{1}$ Program Studi Teknik Mesin Fakultas Teknik, Universitas Udayana, 80316, awatsa@yahoo.com

${ }^{2}$ Program Studi Teknik Mesin Fakultas Teknik, Universitas Udayana, 80316

${ }^{3}$ Program Studi Teknik Mesin Fakultas Teknik, Universitas Udayana, 80316

${ }^{4}$ Program Studi Teknik Mesin Fakultas Teknik, Universitas Udayana, 80316
} 
keperluan lainnya, sementara batoknya dianggap sebagai limbah karena tidak memiliki manfaat bagi kebutuhan hidup sehari hari dan terkadang digunakan hanya sebagai kayu api. Mungkin dari semua bagian pohon kelapa hanya batok yang kurang dimanfaatkan. Batang pohon kelapa bisa digunakan sebagai bahan bangunan, daun biasanya dimanfaatkan untuk membuat kelengkapan upacara di Bali atau bisa juga dibuat ketupat. Buah kelapa sendiri memiliki banyak sekali kegunaan. Namun saat ini batok kelapa yang awalnya dianggap sebagai benda sampah yang mengotori lingkungan diubah menjadi produk kerajinan yang memiliki nilai jual tinggi, tetapi untuk membersihkan serabut yang ada dibatok tersebut sulit karena memerlukan waktu yang banyak namun hasilnya tidak maksimal atau tidak efektif dan tidak efisien. Dilain pihak ada pengerajin yang memerlukan batok kelapa yang sudah bersih dengan kwalitas yang baik dan kapasitas yang banyak.

Cara yang digunakan oleh pengerajin untuk membersihkan serabut-serabut yang ada di batok kelapa saat ini adalah dilakukan secara konvensional atau manual. Pembersihan batok kelapa yang dilakukan secara konvensional yaitu dengan membersihkan sisa serabut halus pada permukaan batok menggunakan amplas kasar, lalu gunakan amplas halus untuk menghaluskan permukaan batok secara merata. Agar permukaan batok bisa mengkilat bisa menggosok permukaan batok menggunakan daun kering secara berulang sampai terlihat mengkilat. Tentunya pembersihan batok kelapa secara konvensional ini memerlukan waktu yang lama dan hasil yang tidak maksimal.

Untuk mengatasi permasalahan ini maka tim pengabdi akan menerapkan teknologi tepat guna yaitu dengan menggunakan mesin pembersih batok kelapa. Karena dengan mesin pembersih batok kelapa ini maka hasil yang diperoleh akan maksimal yaitu lebih halus dan lebih banyak sehingga mampu memenuhi kebutuhan bahan baku untuk produk kerajinan tangan. Oleh karena itu dibutuhkan sebuah alat atau mesin yang mampu mengatasi masalah ini, sehingga pekerjaannya akan lebih efektif dan efisien dan dapat meningkatkan penghasilan atau pendapatan masyarakat..

\section{METODE KEGIATAN}

Metode kegiatan yang dilakukan untuk tercapainya tujuan kegiatan pengabdian ini terlebih dahulu survey ke lingkungan Muding Kelod untuk mengetahui potensi yang ada dan permasalahan dari potensi tersebut. Selanjutnya menyiapkan rancangan gambar alat yang akan diterapkan dan pengadaan mesin pembersih batok kelapa. Setelah terwujud alat pembersih batok kelapa ini dilanjutkan dengan uji coba alat. Kemudian memberikan pengarahan penggunaan dan pengembangan alat. Sebagai tolak ukur maka dilakukan evaluasi terhadap kegiatan dan alat yang selanjutnya dibuatkan laporan kegiatan

Sebelumnya akan dirancang mesin pembersih batok kelapa ini di Laboratorium Prestasi Mesin Teknik Mesin Unud. Rancangan yang dimaksud adalah berupa gambar mesin pembersih batok kelapa. Rancangan akan memperhitungkan berapa kapasitas batok kelapa yang akan mampu dibersihkan sehingga proses pembersihan akan lebih cepat.

\section{REALISASI PEMECAHAN MASALAH}

Pembersihan batok kelapa secara konvensional ini memerlukan waktu yang lama dan hasil yang tidak maksimal, untuk itu diperlukan penerapan teknologi tepat guna yaitu dengan menggunakan mesin pembersih batok kelapa seperti: 

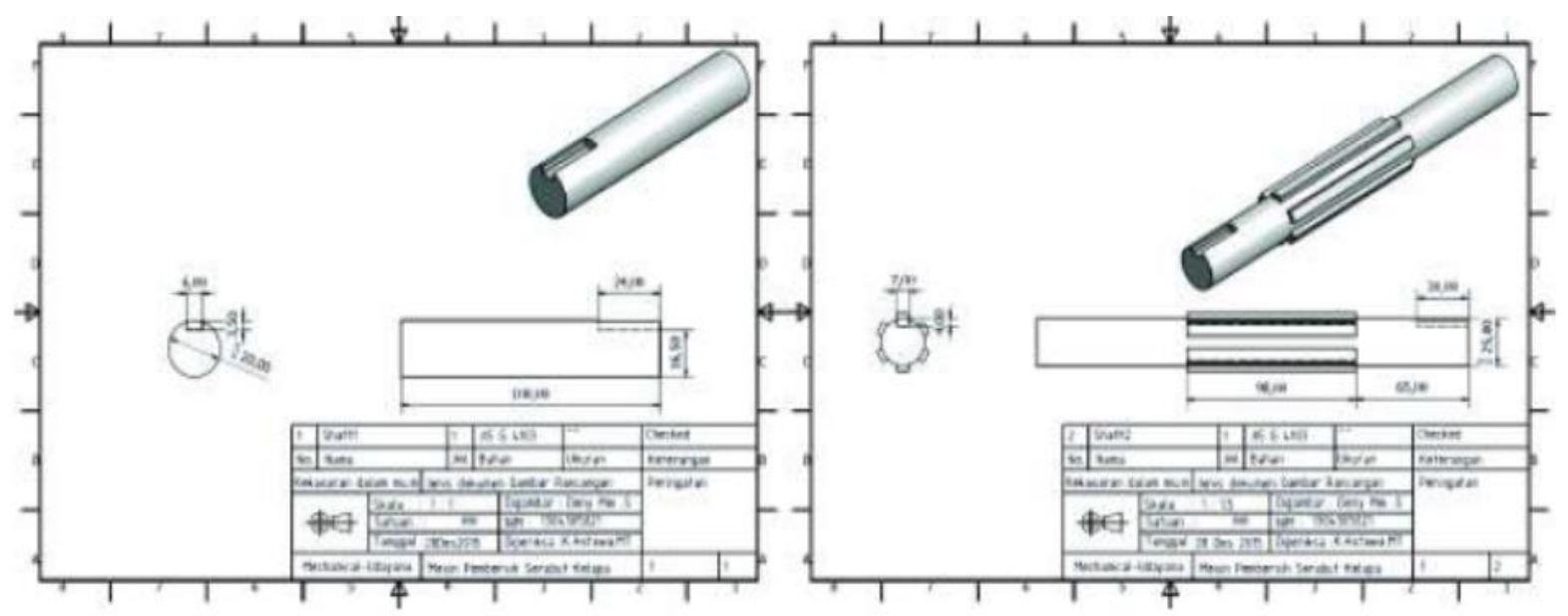

Gambar 3.1. Rancangan poros
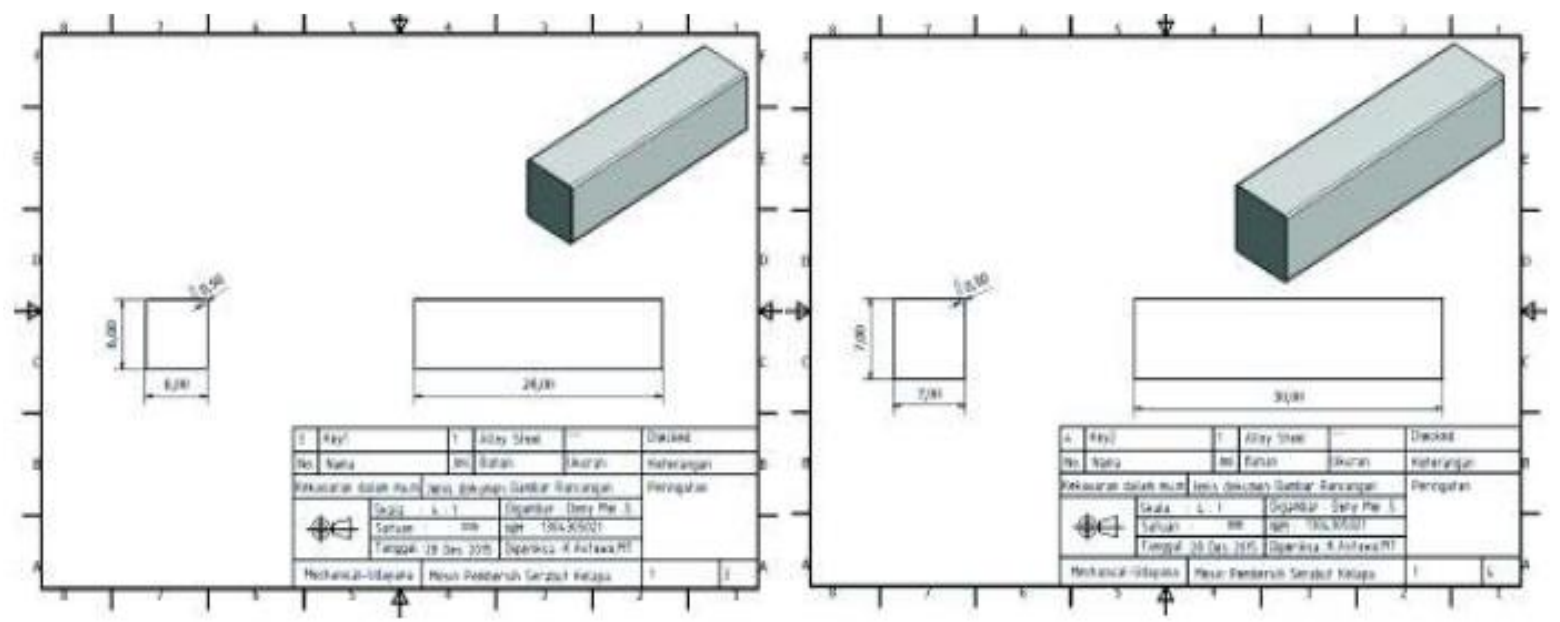

Gambar 3.2. Rancangan pasak
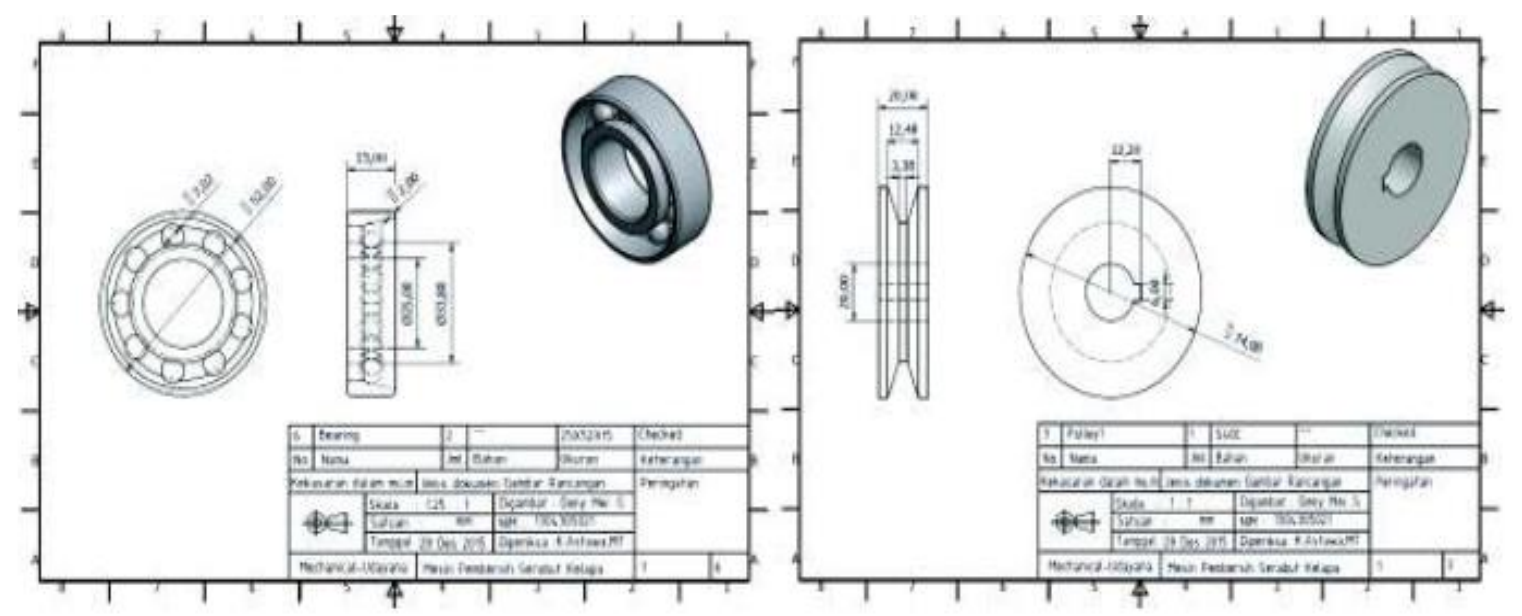

Gambar 3.3. Rancangan bearing dan pulley 


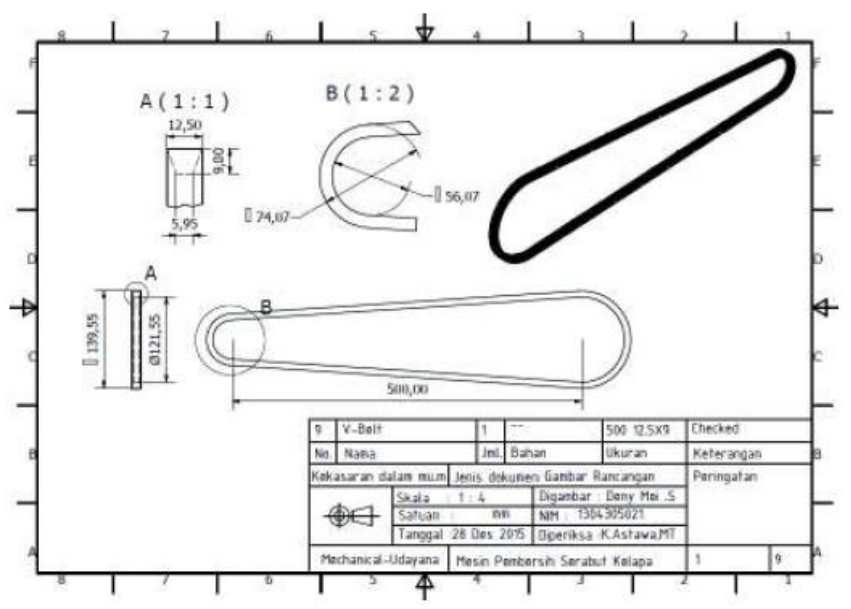

Gambar 3.4. Rancangan belt (sabuk)

9. Pisau Belimbing
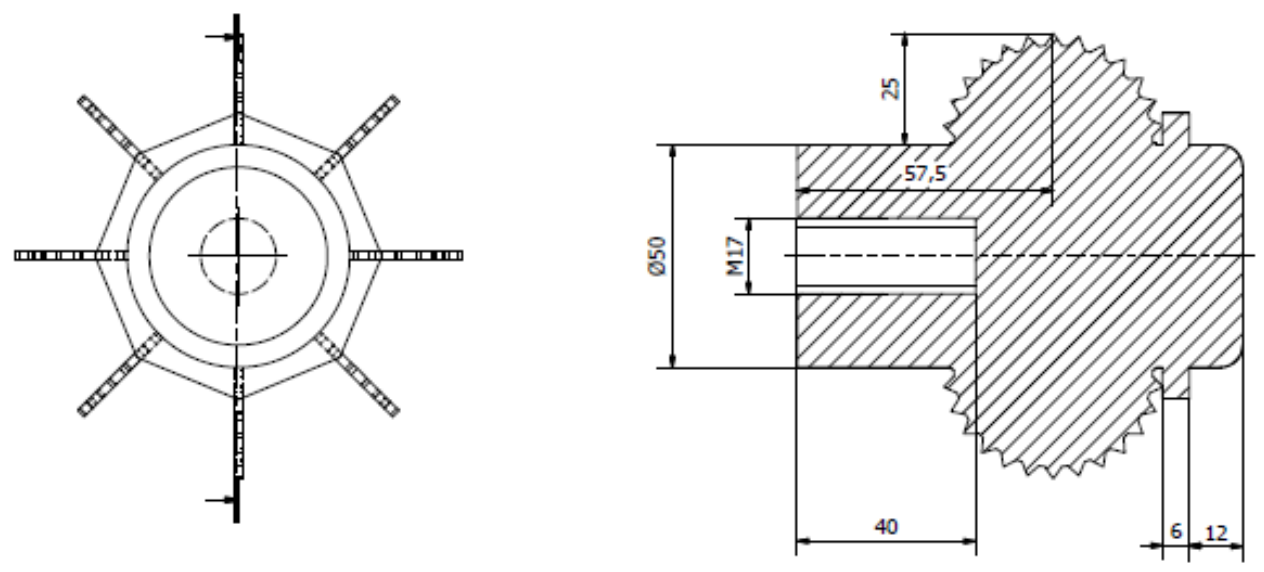

Gambar 3.5 Rancangan Pisau pemarut kelapa
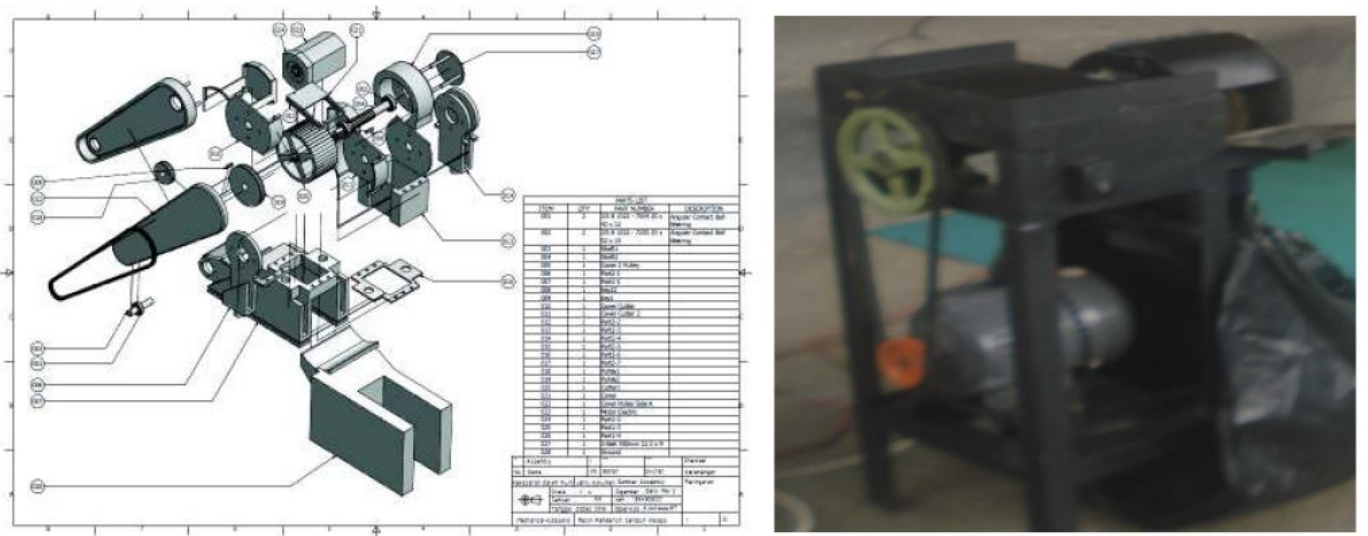

Gambar 3.5. Perakitan/ Assembly dan Konstruksi Pembersih Batok dan Pemarut kelapa 


\section{HASIL KEGIATAN}

\subsection{Data hasil kegiatan}

Tabel 1. Hasil Pelaksanaan Pengabdian

\begin{tabular}{ccc} 
Waktu dan Cara & Konvensional & Mesin \\
\hline Waktu Pembersihan & 15 & 2 \\
Waktu Pemarutan & 30 & 10 \\
\hline
\end{tabular}

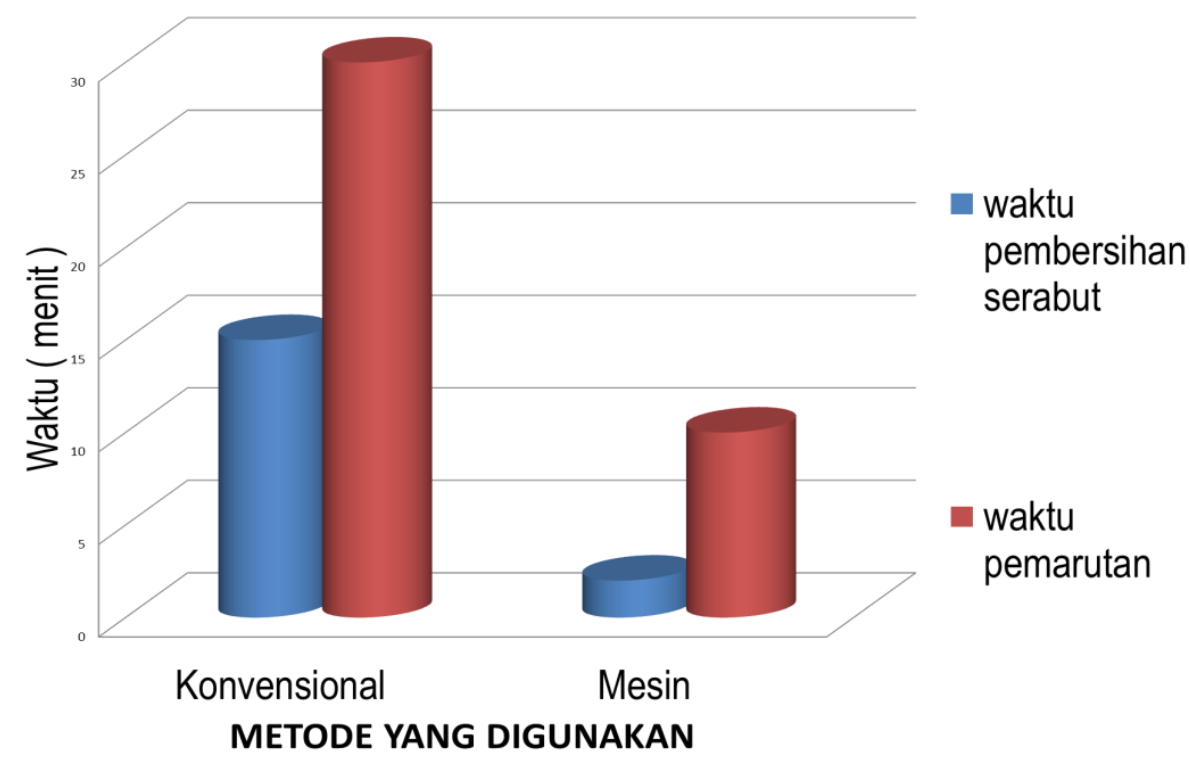

Gambar 4.1 Grafik perbandingan waktu dalam operasional

Hasil yang diperoleh dari pelatihan ini adalah ketrampilan warga bertambah yaitu mampu mengoperasikan mesin dan mempercepat proses pembersihan serabut halus dan lebih efisien waktu dibandingkan dengan membersihkan secara manual dan sekaligus menggunakan alat ini sebagai pemarut kelapa. Perbandingan waktu pembersihan serabut antara cara manual dan dengan mesin adalah 15 menit berbanding 2 menit dan perbandingan waktu pemarutan yaitu 30 menit berbanding 10 menit Sehingga hasil yang diperoleh pun jauh lebih banyak dengan menggunakan mesin, yaitu terjadi peningkatan efisiensi sebesar $13 \%$, artinya apabila dengan cara konvensional menghasilkan 1 kelapa bersih dalam waktu 15 menit maka dengan mesin menghasilkan 1 kelapa bersih dalam waktu 2 menit dan untuk pemarutan dengan jumlah kelapa yang diparut sama meningkat 3 kali lipat. 


\subsection{Hasil Pengabdian}
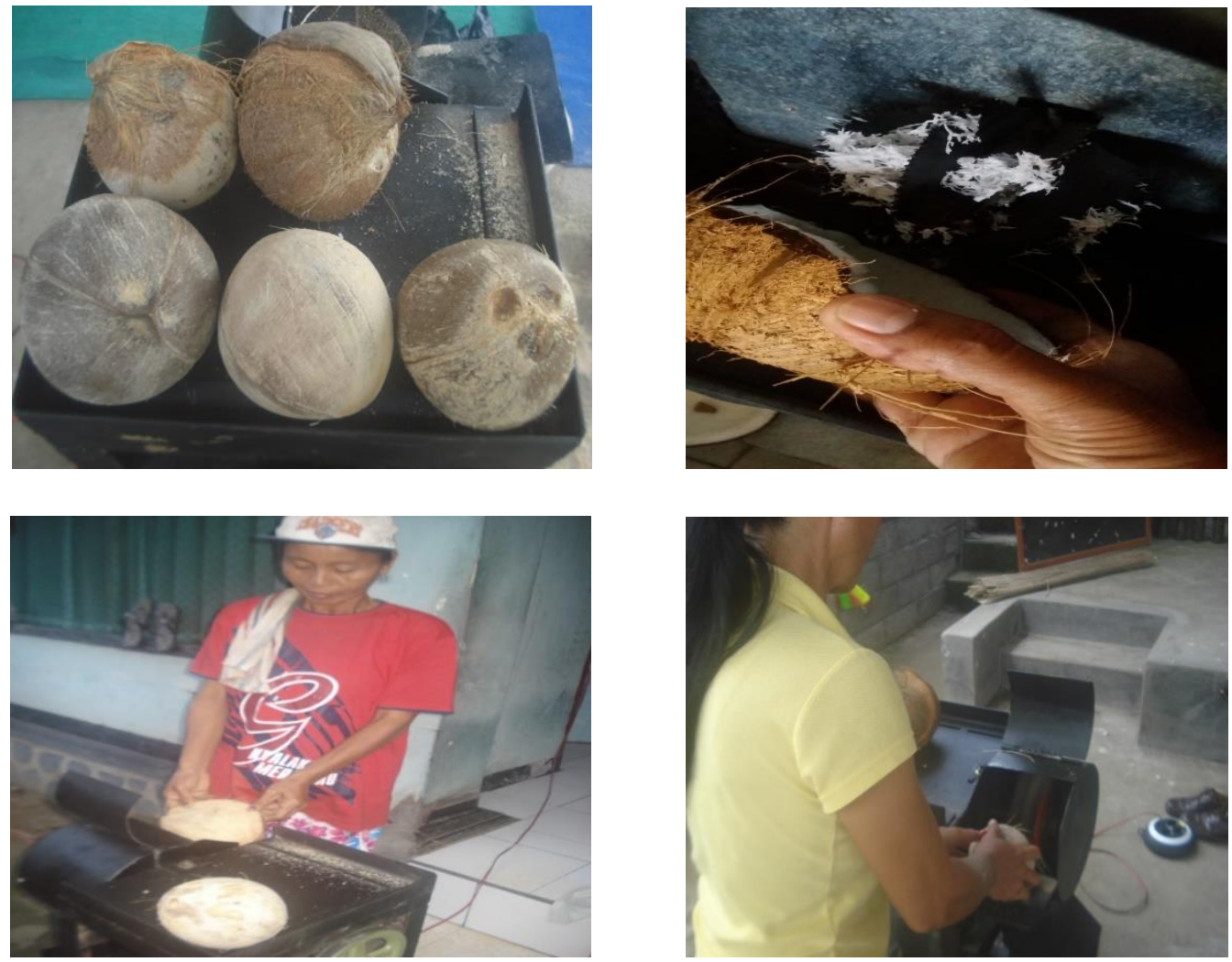

Gambar 4.2 Hasil pembersihan serabut dan pemarutan kelapa

\section{UCAPAN TERIMAKASIH}

Pengabdian ini didanai dengan dana PNBP oleh DIKTI Melalui LPPM dan Fakultas Teknik Universitas Udayana Dengan Surat Perjanjian Penugasan Pelaksanaan Pengabdian Nomor : 1696/UN 14.2.5.II/LT/2018, tanggal 29 Maret 2018

\section{DAFTAR PUSTAKA}

Aaroon D. Duetscman, Waalter J Michel and Caharles E. Wilson,(1975). Machine Disign, United States of America, Macmillian Publishing co inc.

Sularso, Kiyokatsu Suga,(1987). Dasar Perencanaan dan Pemilihan Elemen Mesin, Jakarta, Pradnya Paramita 